Research Article

\title{
Anatomical Characters Used for Defining Five Species of Nepenthes from Bangka Belitung Islands, Indonesia
}

\author{
Sakina Rizqiani, Nunik Sri Ariyanti *, Sulistijorini \\ Department of Biology, Faculty of Mathematics and Natural Sciences, Bogor Agricultural University \\ Bogor 16680, Indonesia
}

\section{Article history:}

Submission December 2017

Revised May 2018

Accepted September 2018

*Corresponding author:

E-mail:nuniksa@gmail.com

\begin{abstract}
Anatomical structures may vary among the species of Nepenthes. Therefore, the anatomical characters apparently could be used for supporting the morphological characters in identifying species. This study aimed to seek a valuable anatomical character for identifying and defining five species of Nepenthes occur in Bangka Belitung Islands. Samples of leaves, pitchers and its lids of Nepenthes gracilis, Nepenthes mirabilis, Nepenthes ampullaria, Nepenthes rafflesiana, and Nepenthes reinwardtiana were collected and prepared for paradermal and transverse section of microscope slides. The results showed that the anatomical characters of the leaves, pitchers and lids from these five species of Nepenthes could be used for differentiating five species Nepenthes observed. The absence of nectary gland at the abaxial of pitcher lids of $N$. gracilis and $N$. ampullaria separate them from others species. The leaf epidermis of these two species have different cell wall. The length of lunate cells at the inner surface of upper half pitchers are comparable for identifying the pitchers of $\mathrm{N}$. mirabilis from those of $N$. reinwardtiana. The presence of crystal at the parenchymal tissue of pitcher differentiate $N$. rafflesiana from the four others. In this research, the identification key for Nepenthes from Bangka Belitung Islands based on the anatomical character was presented.
\end{abstract}

Keywords: Carnivorous plant, lunate cell, nectar gland, taxonomy, Nepenthaceae

\section{Introduction}

Floristic researches on the tropical pitcher plants (Nepenthes) in Indonesia were intensely conducted to explore the species diversity in the large islands such as Sumatra, Kalimantan, Sulawesi and Papua [1]. Since Indonesia has thousands of small islands where speciation may have occurred independently from the main islands; therefore, exploration work for documenting Nepenthes in small islands are challenging. Unfortunately, the sustainability many species of Nepenthes is currently threatened due to, among other things, habitat transformation by human activities. Some species of Nepenthes, for example, Nepenthes rajah are classified as an endangered plant and listed in the appendices I and II of Convention on International Trade of Endangered Species (CITES) of Wild Flora and Fauna [2].
Bangka Belitung Islands is a province located in the northeast of Sumatra, Indonesia. These Islands have various type of lowland habitat for Nepenthes comprise tropical heath forest and lowland tropical rainforest. Five species of Nepenthes occur in this island [3]. However, mining activities are intensively occurred in this island. These activities altered habitats and threatened the biodiversity [4].

Taxonomical studies on Nepenthes genus in Indonesia are more likely based on the morphological characters [5, 6, 7], only a few reports presented the anatomical structures of Nepenthes [8, $9,10]$. The anatomical characters are not widely used in the taxonomy of Nepenthes, yet the discussion on the anatomical characters of Nepenthes is generally associated with structure development, function, and adaptation [11, 12]. This study aims

How to cite:

Rizqiani S, Ariyanti NS, Sulistijorini (2018) Anatomical Characters Used for Defining Five Species of Nepenthes from Bangka Belitung Islands, Indonesia. Journal of Tropical Life Science 8 (3): 311 - 322. doi: 10.11594/jtls.08.03.14 
to provide information on the comparative anatomical character of Nepenthes, use these characters to construct key identification to the Nepenthes species of Bangka Belitung Islands and add this anatomical character to the morphological description of these species.

\section{Material and Methods Collecting plant materials}

Five Nepenthes species (Nepenthes gracilis, Nepenthes mirabilis, Nepenthes ampullaria, $\mathrm{Ne}$ penthes rafflesiana, and Nepenthes reinwardtiana) were obtained from lowland habitats (01000 masl) at Bangka Belitung Islands, Indonesian in September 2016. The plant material (leaves, pitchers and lid of the pitchers) of those species were collected and fixed in $70 \%$ alcohol for the preparation of anatomical slide in the laboratory. Samples of the pitchers were divided into upper half and lower half. So that the parts sliced are divided into eight parts namely, abaxial leaf, adaxial leaf, abaxial pitcher's lid, adaxial pitcher's lid, inner surface upper half of the pitcher, outer surface upper half of the pitcher, inner surface lower half of the pitcher, outer surface lower half of the pitcher and inner surface lower half of the pitcher. All parts replicated three times. Observations were made on five field of view in $10 \times$ and $40 \times$ magnification for each section made.

\section{Preparing paradermal and transverse section}

Samples of the plant materials were prepared for the abaxial and adaxial (leaves and pitcher's lids), outer and inner (pitchers) paradermal section by using wholemount method that has been modified [13]. The fixed samples were immersed in $\mathrm{HNO}_{3} 20 \%$ solution for $25-40$ minutes to allow the epidermal layer to be easily released from the mesophyll tissues. A layer of the epidermis scraped using a razor blade. Furthermore, the epidermal layer was immersed in chlorox to clear off any remaining dirt or tissue. The epidermal layer was placed on a petri dish and stained with $1 \%$ safranin for $2-4$ minutes, then the epidermal layer was washed with aquades, then placed on a glass object, added with 1 to 2 drops of $30 \%$ glycerin and covered with a glass cover.

The transverse section was made by following the frozen microtome methods [13]. The fresh samples were cut to $0.5 \times 0.5 \mathrm{~cm}$ then fixed in FAA solution for 24 hours. The fixed samples were cut with the Yamato RV-240 frozen microtome for obtaining a thickness of 18 to $20 \mu \mathrm{m}$. The sliced samples were subsequently soaked in water to separate the transverse section and then stained with $0.5 \%$ safranin solution for \pm 1 minute. The stained samples then washed with water and placed on a glass object and glued with a drop of $30 \%$ glycerin and covered with a glass cover.

\section{Characters observation}

Microscope slides of paradermal and transverse section of leaves, pitcher, and lid of the pitchers were observed under compound microscope Olympus CX21 with $10 \times 10$ and $10 \times 40$ magnification. Photographs of the anatomical structure were taken using Optilab Viewer ${ }^{\circledR}$ v.2.1. The characters of epidermal cells, stomata, and trichome were observed at the abaxial and adaxial of leaves and lids as well as the outer surface of pitchers; the epidermal cells, lunate cells, nectar glands and digestive glands were observed at the inner pitchers. The structure and characters of epidermis, hypodermis, mesophyll, and others were surveyed at transverse section of leaves, pitchers and the lids

\section{Results and Discussion \\ Paradermal strucutures}

The leaves of five Nepenthes species collected from Bangka Belitung Islands have polygonal epidermal cells with either straight or sinuous walls (Figure 1). The cells shape of epidermal leaves was previously considered as a good diagnostic character for identifying species [14]. It is applicable in some case such as Pandanus [15]. In the case of Nepenthes, this genus could be described as having the polygonal epidermal cells with either straight or sinuous walls. However, this character is not specific for the genus Nepenthes. Many other plants, such as Solanum [16], have similar characters to the epidermal cells of Nepenthes leaves. Therefore, this anatomical character cannot be used alone as a diagnostic character of this taxon, but it can be used for supporting the morphological diagnostic characters.

The character of epidermal cell leaves that could be used for identifying the Nepenthes species of Bangka Belitung is whether the character of epidermal cell walls at adaxial surface of the leaves is similar or different from that at abaxial surface of the leaves. The Nepenthes species col- 


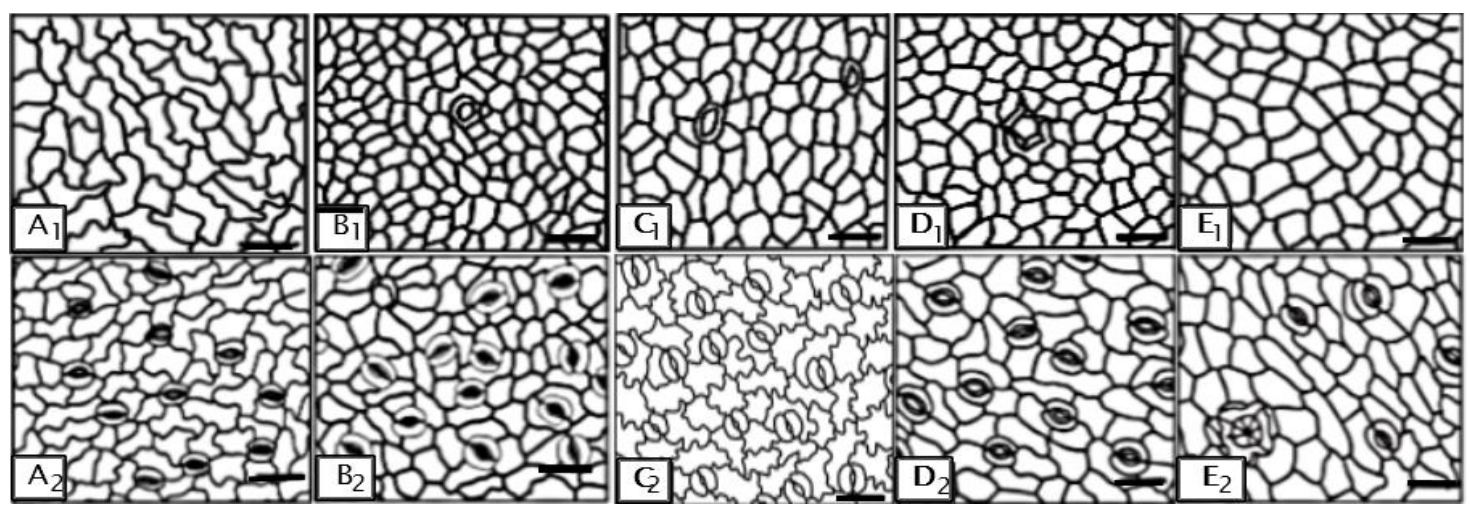

Figure 1. Paradermal section of adaxial (top row) and abaxial (bottom row) leaves of five species Nepenthes of Bangka Belitung (Note: N. gracilis (A), N. mirabilis (B), N. ampullaria (C), N. rafflesiana (D) and $N$. reinwardtiana $(\mathrm{E})($ scale bar $=50 \mu \mathrm{m}))$

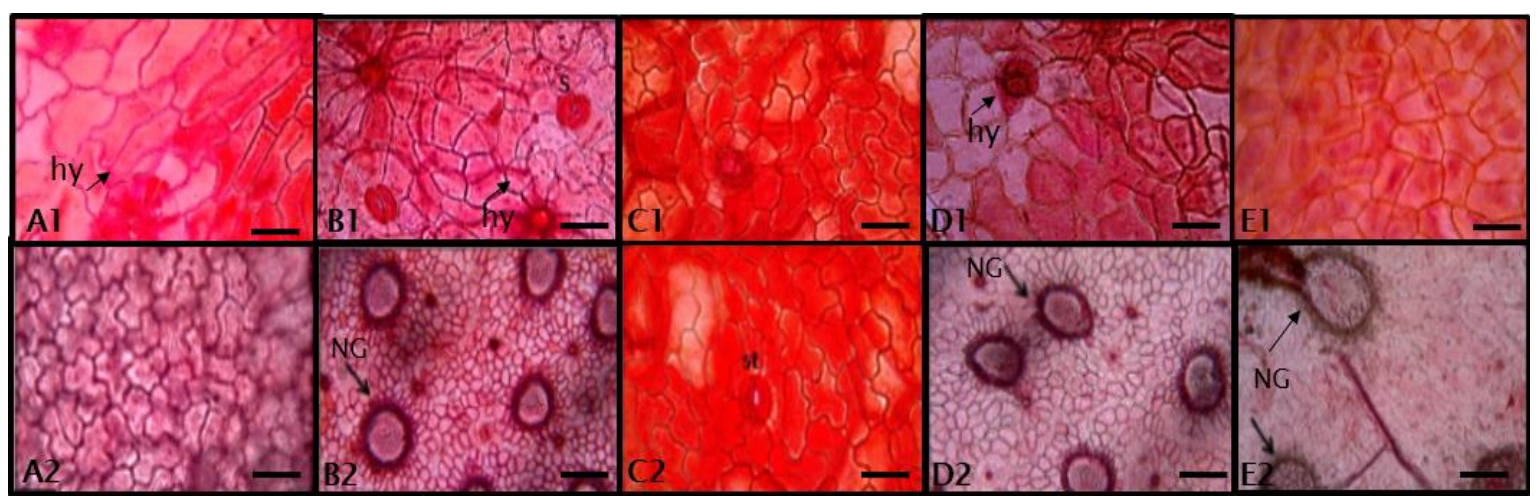

Figure 2. Paradermal section of adaxial (top rows) and abaxial (bottom rows) pitcher lid of five Nepenthes species of Bangka Belitung. (Note: N. gracilis (A), N. mirabilis (B), N. ampullaria (C), N. rafflesiana (D), $N$. reinwardtiana (E). hy: hydathode; NG: nectary gland; st: stoma. Scale bar abaxial (A1-E1) = $100 \mu$ m; adaxial $(\mathrm{A} 2-\mathrm{E} 2)=30 \mu \mathrm{m})$

Table 1. Average length of the leaf epidermal cells of five species Nepenthes from Bangka Belitung Islands

\begin{tabular}{lcc}
\hline \multirow{2}{*}{ Species } & \multicolumn{2}{c}{ The Average Length of Epidermal Cells } \\
\cline { 2 - 3 }$N$. gracilis & Adaxial $(\mu \mathrm{m})$ & Abaxial $(\mu \mathrm{m})$ \\
N. mirabilis & $44 \pm 5.47$ & $43 \pm 3.77$ \\
N. ampullaria & $23 \pm 4.10$ & $38 \pm 4.24$ \\
$N$. rafflesiana & $25 \pm 6.27$ & $27 \pm 3.26$ \\
N. reinwardtiana & $36 \pm 8.21$ & $42 \pm 4.10$ \\
\hline
\end{tabular}

lected from Bangka Belitung Islands have similar type of epidermal cells in both adaxial and abaxial side of the leaves, except for $N$. ampullaria, which has epidermal cells with a sinuous wall on the abaxial and straight wall on the adaxial leaf surface (Figure 1). However, this case is also found in the leaves of Nepenthes bicalcarata from West Borneo, which also have epidermal cells with a straight wall in the adaxial leaf and sinuous wall in the abaxial side of the leaf [17]. The species $N$. gracilis has a slightly sinuous wall in the epider- mal cells in both abaxial and adaxial surface of the leaves; the other three species have a straight wall of epidermal cell in both abaxial and adaxial surface of the leaves (Figure 1).

The paradermal leaf section of five Nepenthes species of Bangka Belitung cannot be separated on the basis of the average length of epidermal cells since it is a continue character. Although the adaxial epidermal cells of N. mirabilis are shorter compare with those of $N$. reinwardtiana and N. gracilis, they are not significantly distinct from those 


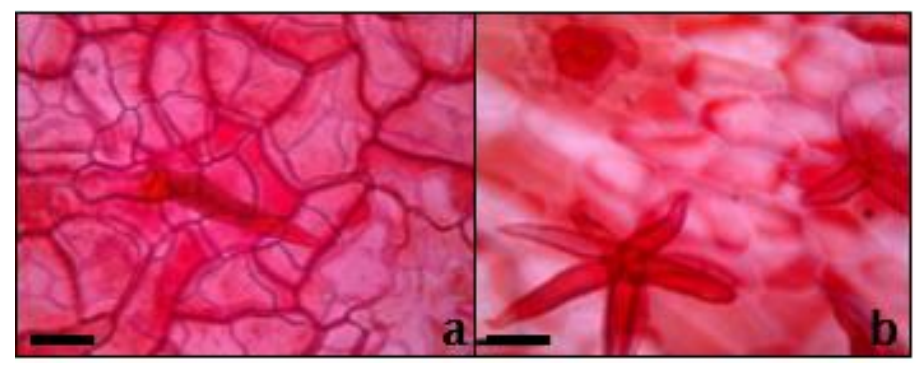

Figure 3. Glandular trichome (A) and Non-glandular trichome (B) (scale bar $=50 \mu \mathrm{m})$

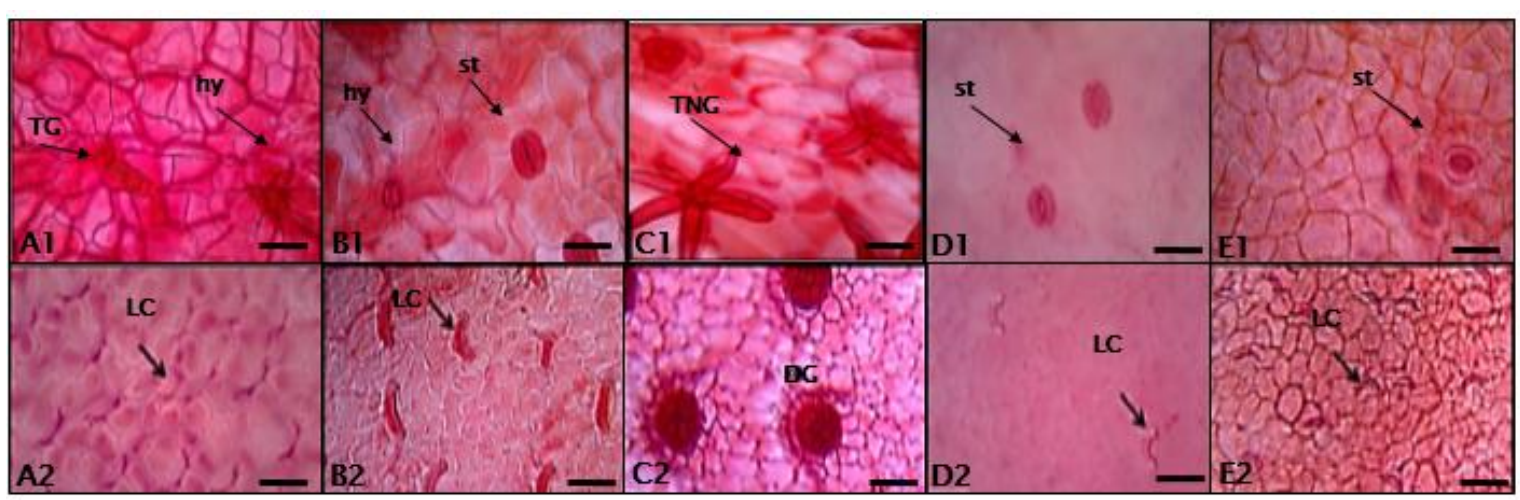

Figure 4. Paradermal sections of the outer (top rows) and inner (bottom rows) surface of upper half pitchers of five Nepenthes species of Bangka Belitung. (Note: N. gracilis (A), N. mirabilis (B), N. ampullaria (C), $N$. rafflesiana (D), N. reinwardtiana (E). DG: digestive gland; Hy: hydatoda; LC: lunate cell; st: stoma; TG: glandular trichome; TNG: non glandular trichome $($ Scale bar $=40 \mu \mathrm{m})$ )

of $N$. ampularia and N. rafflesiana (Table 1). The epidermal cells of abaxial surface tends to be longer than those of the adaxial surface (Table 1), this is similar to the case of Nepenthes species found in West Borneo (N. veitchii, N. bicalcarata, $N$. clipeata, $N$. neglecta, and $N$. hirsuta) [17].

A spherical channel-like structure of hydathodes are sparsely distributed on the epidermis of adaxial leaves (Figure 2). This structure is present not only in leaves but also on the epidermal section of the outer surface of the pitchers and stems [14]. Hydathode is a type of pore, that secrete water or salt out of the leaf through an active process [18].

Stomata are absent on the adaxial leaf surfaces of five Nepenthes species from Bangka Belitung. However, anomositic stomata that have subsidiary cells similar to the epidermal cells are found on abaxial leaf surfaces of those species (Figure 1). Nepenthes do not specifically have anomositic stomata, another stomata type occur in this genus. The species of $N$. bicalcarata has actinocytic stomata, the guard cells are surrounded by a circle of radiating subsidiary cells [17]. Multicellular nonglandular and multicellular glandular trichomes are found on both abaxial and adaxial leaf surfaces of the Nepenthes species from Bangka Belitung Islands (Table 2). The glandular trichomes are uniseriate, while the non-glandular trichomes are stellated (Figure 3).

The epidermal characters of adaxial pitcher lid surfaces are similar to those of the adaxial leaf surface, in terms the shape of epidermal cells, type of stomata, hydathodes, and trichomes. The epidermal cells of the abaxial lid surface are similar to that of the adaxial lid surface is found in N. gracilis and $N$. ampullaria. However, the epidermis of abaxial pitcher lid surface of the three others $\mathrm{Ne}$ penthes differs from their adaxial lid surface. It consists of nectary glands and smaller polygonal cells (Figure 2). This extra floral nectary glands of Nepenthes are oval and consist of many well-ordered cells. The largest nectary glands among the Nepenthes of Bangka-Belitung was found at the lid of $N$. rafflesiana, while those the smallest occurred at the lid of $N$. mirabilis (Table 3). Nectary glands produce nectar used to attract prey such as invertebrate, insect and arthropod [20]. The nectary glands have a solid cytoplasm and a small va- 
Table 2. Comparison of anatomical structures occur on the epidermal layer of leaf, pitcher, and lid among the five species of Nepenthes of Bangka Belitung.

\begin{tabular}{|c|c|c|c|c|c|c|c|}
\hline Organ & Surface & Structure & $\begin{array}{c}N . \\
\text { gracilis }\end{array}$ & $\begin{array}{l}N . \\
\text { mirabilis }\end{array}$ & $\begin{array}{c}N . \\
\text { ampullaria }\end{array}$ & $\begin{array}{c}N . \\
\text { rafflesiana }\end{array}$ & $\begin{array}{c}N . \\
\text { reinwardtial } \\
\end{array}$ \\
\hline \multirow[t]{3}{*}{ Leaf } & Adaxial & 1. Trichomes & Absent & Absent & Absent & Absent & Absent \\
\hline & & 2. Hydathodes & Present & Present & Present & Present & Present \\
\hline & Abaxial & 3. Stomata & Present & Present & Present & Present & Present \\
\hline \multirow{3}{*}{$\begin{array}{l}\text { Pitcher } \\
\text { lid }\end{array}$} & Adaxial & 4. Trichomes & Absent & Absent & Absent & Absent & Absent \\
\hline & & 5. Hydathodes & Present & Present & Present & Present & Present \\
\hline & Abaxial & 6. Nectary glands & Absent & Present & Absent & Present & Present \\
\hline \multirow[t]{4}{*}{ Pitcher } & Outer & 7. Trichomes & GT & NGT & NGT & NGT & Absent \\
\hline & & 8. Hydathodes & Present & Present & Present & Present & Present \\
\hline & Inner & 9. Lunate cells & Present & Present & Absent & Present & Present \\
\hline & & $\begin{array}{l}\text { 10. Digestive } \\
\text { glands }\end{array}$ & Present & Present & Present & Present & Present \\
\hline
\end{tabular}

Tabel 3. Average length and density of nectary glands on the abaxial lid surfaces of five Nepenthes species of Bangka Belitung.

\begin{tabular}{lcc}
\hline \multicolumn{1}{c}{ Species } & Lenght $(\mu \mathrm{m})$ & Density per $\mathrm{mm}^{2}$ \\
\hline$N$. gracilis & - & - \\
N. mirabilis & $123.2 \pm 6.7$ & $18.2 \pm 0.7$ \\
N. ampullaria & - & - \\
$N$. rafflesiana & $198.3 \pm 3.4$ & $3.10 \pm 0.3$ \\
$N$. reinwardtiana & $138.0 \pm 9.5$ & $8.50 \pm 0.5$
\end{tabular}

cuole containing tannin [21].

Nectary glands are absent at the lids of $N$. gracilis and $N$. mirabilis. It was reported that the extra floral nectary glands may occurs on the other part of pitchers, such as it is found in peristome of $N$. fusca pitchers [19]. The pitchers of $N$. fusca morphologically resemble those of $N$. gracilis.

The paradermal section of the outer surface of both the upper and lower half part of pitchers are homogenous to those of the adaxial surface of the leaves and pitcher lids. Anomositic stomata, uniseriate glandular or stellate non-glandular trichomes, and hydathodes are present among the polygonal epidermal cells. The pitchers and its lids of Nepenthes are modified leaves, thereby the anatomical structures of the outer surface of pitchers, the adaxial surface of lids and leaves are similar [9].

The paradermal structure of inner surface of upper half pitchers are composed of small polygonal cells and semicircular sickle (lunate) cells. Such a structure is found in $N$. gracilis, N. mirabilis, $N$. rafflesiana, and $N$. reinwardtiana but absence in $N$. ampullaria (Figure 4). A report on pitcher plants stated that the presence of lunate cell related to the presence of crystalline wax at the inner surface of its pitchers; therefore, it is called waxy zone. The lunate cell has a function in denying traction to the claws of invertebrates travelling in an upward direction forming a smooth and wavy surface of the pitcher [22]. The waxy zone serves as a trap for prey since the adhesive waxy surface prevent the prey from escaping [19].

The lunate cell at inner surface of upper half pitchers were found at the species that have elongated cylindrical pitchers. These pitchers can be divided clearly into waxy and digestive zones (Figure 5). Despite that the lunate cells at the inner pitcher surface of $N$. ampullaria is absent, this inner surface is composed by epidermal cells and the digestive glands. This species has a short cupshape pitcher that cannot be morphologically divided into two different zone. This absence of waxy zone in the pitcher of $N$. ampullaria is in line with other report [23].

The presence or absence of the lunate cell is a distinct character that can be used in distinguishing a species in the genus Nepenthes. The platelet- 


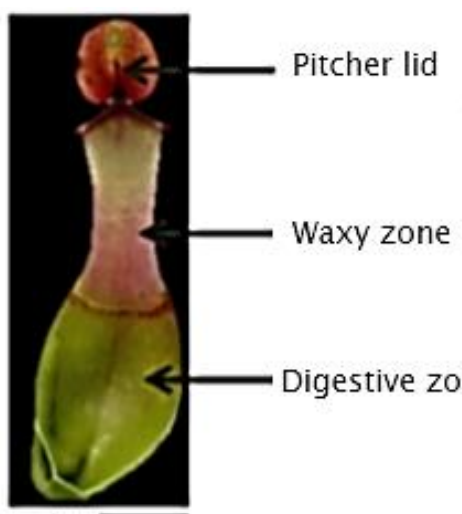

(a) $\overline{2 \mathrm{~cm}}$

Figure 5. The pitcher of Nepenthes comprises of waxy zone at the upper half and digestive zone at lower half. (Note: N. gracilis (A) and $N$. rafflesiana (B))

Table 4. Average length and density of lunate cells on the inner surface of upper half pitchers of five species Nepenthes species of Bangka Belitung

\begin{tabular}{|c|c|c|}
\hline Species & $\begin{array}{l}\text { Length } \\
(\mu \mathrm{m})\end{array}$ & $\begin{array}{c}\text { Density } \\
\left(\text { per } \mathrm{mm}^{2}\right)\end{array}$ \\
\hline N. gracilis & $52.7 \pm 2.0$ & $49.2 \pm 0.5$ \\
\hline N. mirabilis & $42.7 \pm 2.0$ & $28.6 \pm 2.0$ \\
\hline N. ampullaria & - & - \\
\hline N. rafflesiana & $38.0 \pm 5.7$ & $5.0 \pm 0.0$ \\
\hline N. reinwardtiana & $59.0 \pm 3.2$ & $9.8 \pm 0.9$ \\
\hline
\end{tabular}

Table 5. Average length and density of digestive glands at the inner surface of lower half pitchers of five species Nepenthes species of Bangka Belitung.

\begin{tabular}{lcc}
\hline \multicolumn{1}{c}{ Species } & $\begin{array}{c}\text { Length } \\
(\mu \mathrm{m})\end{array}$ & $\begin{array}{c}\text { Density } \\
\left(\mathrm{per} \mathrm{mm}^{2}\right)\end{array}$ \\
\hline N. gracilis & $193.5 \pm 1.8$ & $6.8 \pm 0.9$ \\
N. mirabilis & $27.0 \pm 1.7$ & $5.6 \pm 2.1$ \\
N. ampullaria & $73.7 \pm 3.3$ & $60.8 \pm 2.6$ \\
N. rafflesiana & $55.3 \pm 2.8$ & $96.3 \pm 0.6$ \\
N. reinwardtiana & $56.3 \pm 3.5$ & $24.6 \pm 0.6$ \\
\hline
\end{tabular}

Table 6. Leaf thickness of the five Nepenthes species of Bangka Belitung

\begin{tabular}{ll}
\hline \multicolumn{1}{c}{ Species } & Thickness $(\mu \mathrm{m})$ \\
\hline N. gracilis & $323.64 \pm 3.26$ \\
$N$. mirabilis & $234.51 \pm 1.27$ \\
N. ampullaria & $212.68 \pm 0.24$ \\
N. rafflesiana & $249.37 \pm 2.30$ \\
N. reinwardtiana & $412.23 \pm 2.40$ \\
\hline
\end{tabular}

shape of lunate cells is not various among the species of Nepenthes [19, 24, 25, 26]. However, the size and density of lunate cells are various among five Nepenthes species from Bangka Belitung. The species $N$. reinwardtiana has the largest size $(59.0 \pm 3.2 \mu \mathrm{m})$ but the lowest density (9.8 per $\left.\mathrm{mm}^{2}\right)$ of lunate cell. The smallest $(38.0 \pm 5.7 \mu \mathrm{m})$ lunate cells are found in $N$. rafflesiana and the highest density (49.2 per $\mathrm{mm}^{2}$ ) are found in $N$. gracilis (Table 4).

The paradermal structure of the inner lower half pitchers which comprise small polygonal cells and digestive glands were observed in the five $\mathrm{Ne}$ penthes species from Bangka Belitung (Figure 6). These digestive glands are multicellular, either rounded ( $N$. gracilis, $N$. ampullaria, and N. mirabilis) or oval ( $N$. reinwardtiana and $N$. rafflesiana), consist of dense cells (Figure 6). The largest size $(55.3 \pm 2.8 \mu \mathrm{m})$ and the highest density of digestive glands (96.3 per $\mathrm{mm}^{2}$ ) are showed in $N$. rafflesiana (Table 5). This gland secretes digestive enzymes to degrade prey so that the nutrients can be absorbed [27].

\section{Transverse structures}

The structure of leaf transverse section composes of one layer of epidermal cells with a thin cuticle at the outer layer (Figure 7). The thickness of cuticle is diverse among the species of Nepenthes and is influenced by the environment [17]. The cuticle on Nepenthes is a waxy structure that has a function in reducing evaporation. There are $1-2$ layers of hypodermis inside the epidermal layer (Figure 7G). This character is common in other Nepenthes species [12]. The hypodermal cells are larger than epidermal cells. The leaves of Nepenthes are bifacial, which is characterized by the mesophyll is differentiated into palisade parenchyma at the top layer and sponge parenchyma at the bottom layer. The thickness leaves of Nepenthes are varying among the species observed. It is probably affected by the environmental factor. Based on the field observation (Table 6), the species which is growing in higher elevation and drier habitat, for example $N$. reinwardtiana, have thicker leaves than those growing at the swamp habitat in lower elevation. The species $N$. gracilis have the intermediate thickness compare to $N$. reinwardtiana and $N$. mirabilis. This species is commonly found in many lowland habitats in 


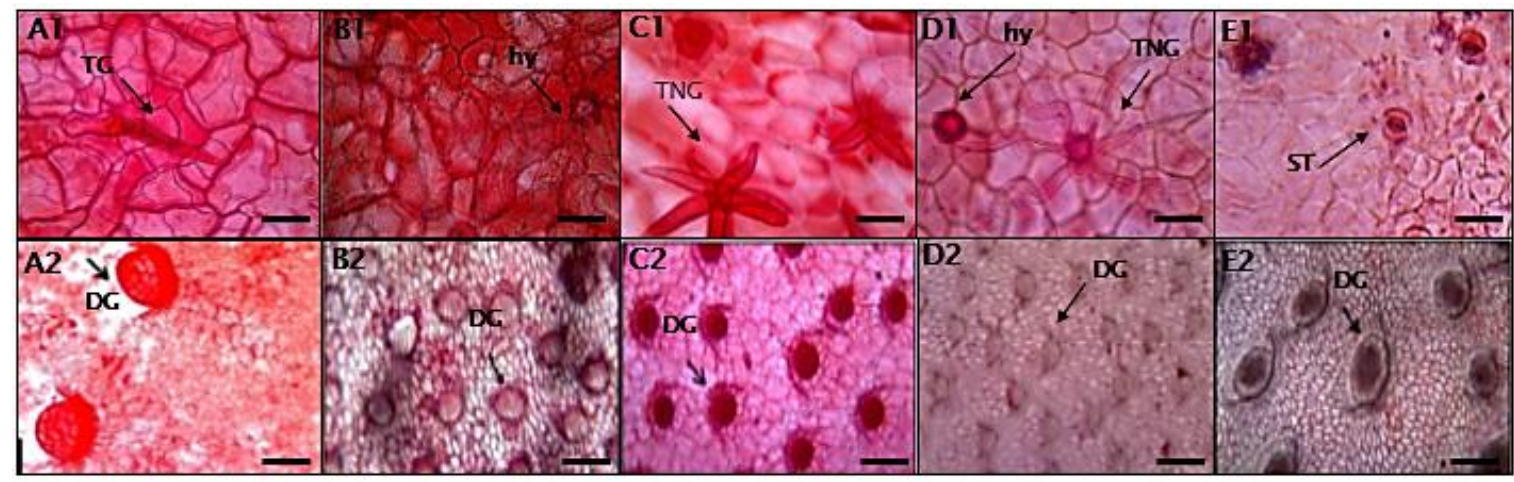

Figure 6. Paradermal section of outer (top rows) and inner (bottom rows) surfaces lower half pitcher of five Nepenthes species of Bangka Belitung. (Note: N. gracilis (A), N. mirabilis (B), N. ampullaria (C), $N$. rafflesiana (D), N. reinwardtiana (E) DG: digestive gland; hy: hydatoda; st: stoma; TG: uniselular trichome; TNG: non glandular trichome (Scale bar $=50 \mu \mathrm{m})$ )

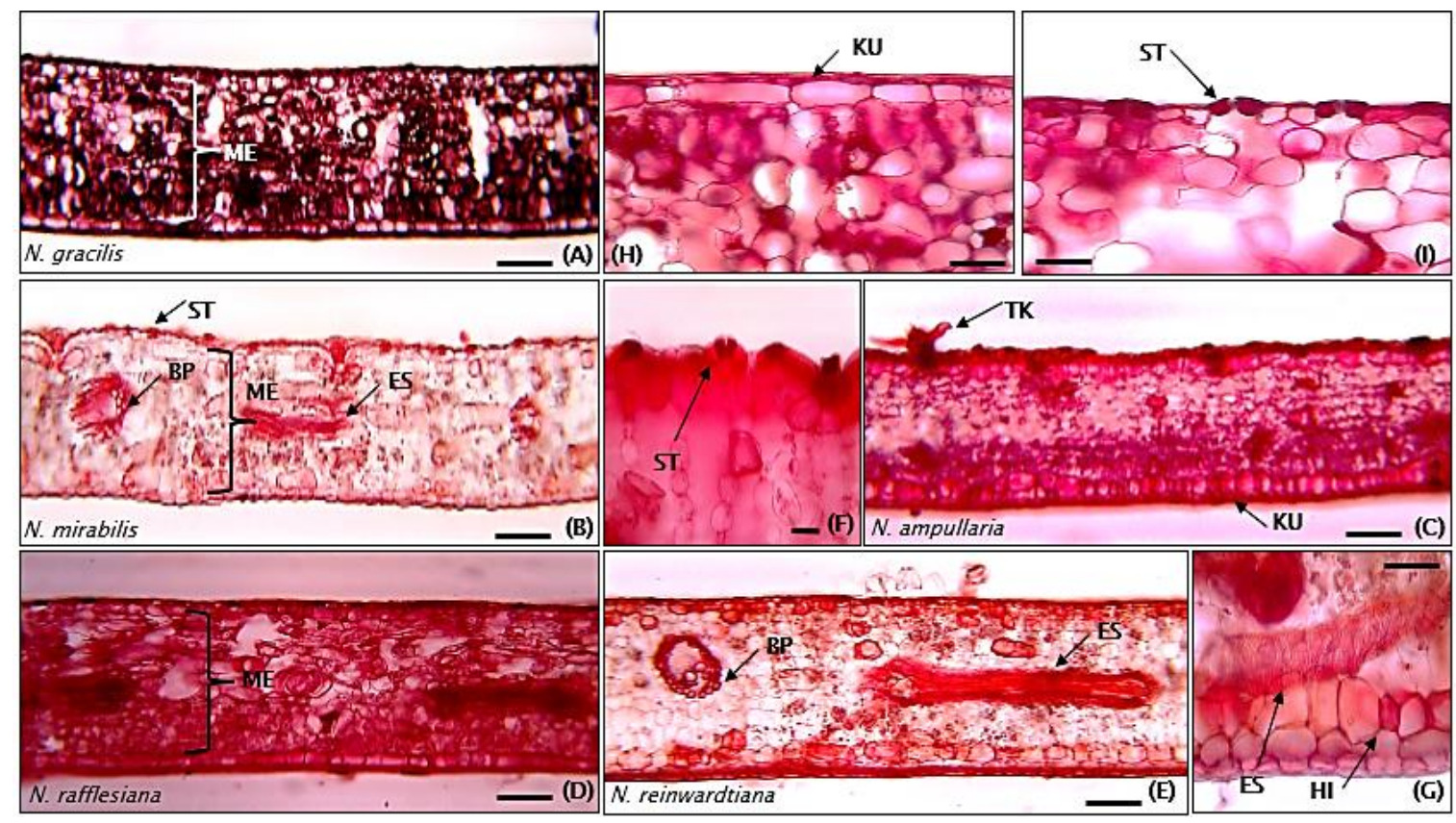

Figure 7. The leaf transverse sections of five Nepenthes species. (Note: N. gracilis (A, H, I); N. mirabilis (B, F); N. ampullaria (C); N. rafflesiana (D); N. reinwardtiana (E, G); N. ampullaria (F). BP: vascular bundle; ES: spiral element; HI: hydathode; KU: cuticle; ME: mesophyll; ST: stoma; TK: non-glandular trichome. Scale bar $(\mathrm{A}-\mathrm{E})=100 \mu \mathrm{m} ;(\mathrm{F}-\mathrm{I})=30 \mu \mathrm{m}))$

Bangka Belitung such as heath forest and secondary forest.

The stomata observed at the leaf transverse section did not showed variation among the observed species ( $N$. gracilis, $N$. ampullaria, $N$. mirabilis, $N$. rafflesiana, and $N$. reinwardtiana), the stomata are protruding above the epidermal cell layer (Figure 7F). Although the stomata that sunken below the surface of epidermis may occur among the Nepenthes [17], this type of stomata was not found in the five species of Nepenthes ob- served.

The transverse sections of pitcher lids are different with those of leaves in term of the mesophyll are not differentiated into sponge and palisade tissue, and the presence of nectary glands. These glands were observed at the epidermal cell of abaxial surface of the three Nepenthes species of Bangka Belitung and absent at the two others (Figure 8 ). The nectary glands, which could be found at the pitchers and lids, are an extra-floral nectary derived from the development of epider- 


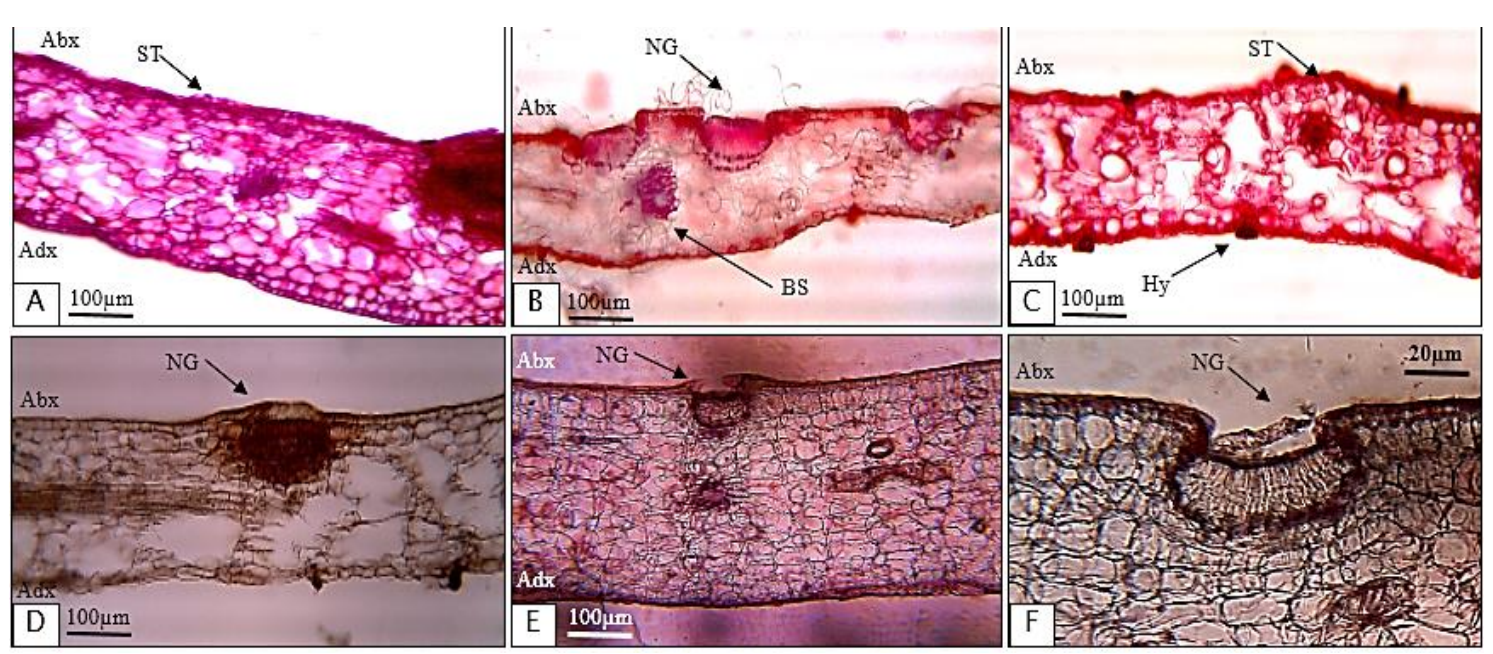

Figure 8. The transverse sections of pitcher lid from five species Nepenthes of Bangka Belitung. (Note: $N$. gracilis (A); N. mirabilis (B); N. ampullaria (C); N. rafflesiana (D); N. reinwardtiana (E); Nectary gland structure in N. reinwardtiana (F). Abx: Abaxial surface; Adx: Adaxial surface; BS: vascular bundle; HY: hydathode; NG: nectary gland; ST: stoma))

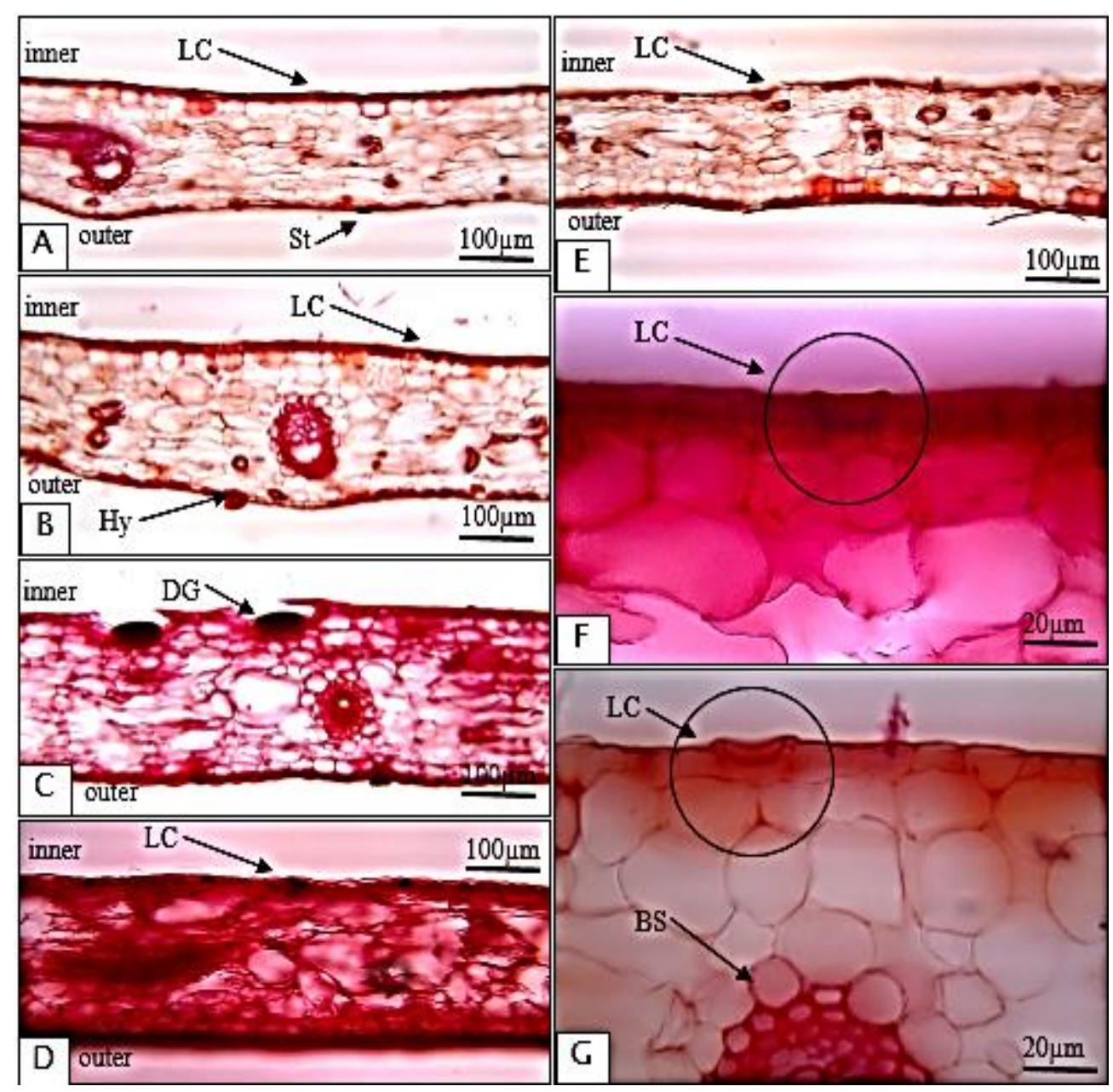

Figure 9. The transverse section of upper half pitcher (waxy zone) of five species Nepenthes of Bangka Belitung. (Note: N. gracilis (A); N. mirabilis (B); N. ampullaria (C); N. rafflesiana (D, F); N. reinwardtiana (E); Lunate cell as it is appeared in N. rafflesiana (F, G). BS: vascular bundle; DG: digestive gland; HY: hydathode; LC: lunate cell; ST: stoma)) 


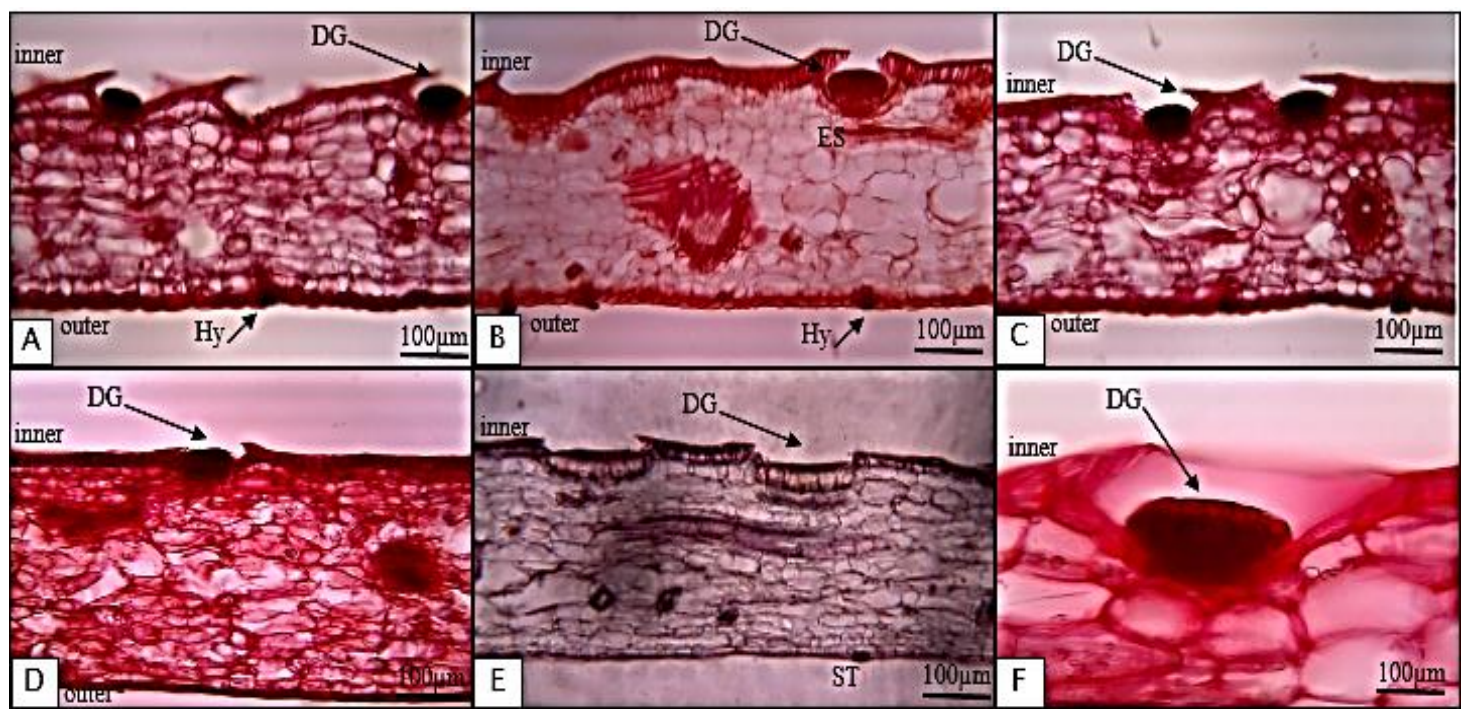

Figure 10. The transverse sections of lower half (digestive zone) pitcher of five species Nepenthes species of Bangka Belitung. (Note: N. gracilis (A); N. mirabilis (B); N. ampullaria (C); N. rafflesiana (D); N. reinwardtiana (E); N. ampullaria (F). DG: digestive glands; HY: hydatode; ST: stomata)

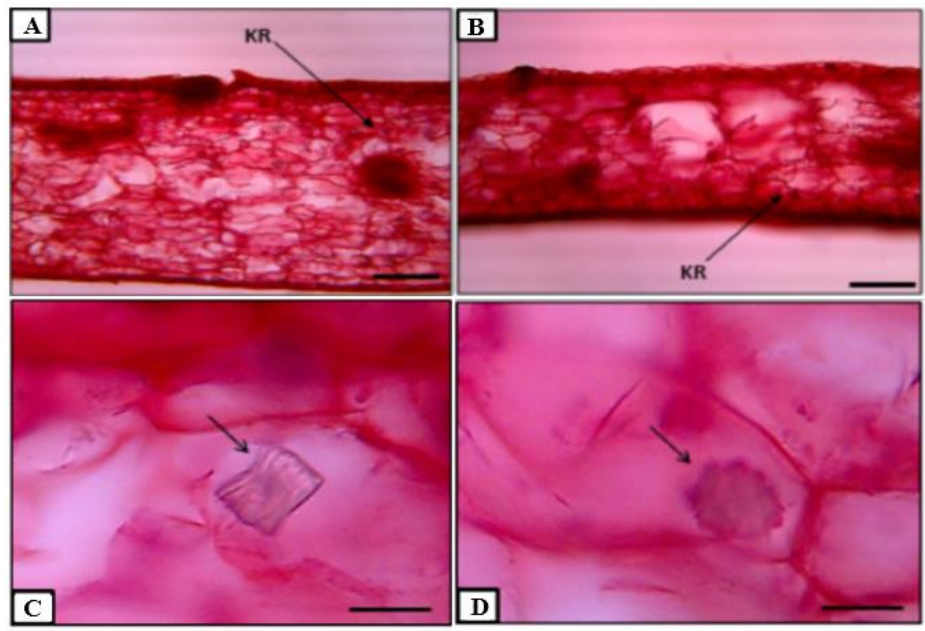

Figure 11. Transverse sections of the pitcher of N. rafflesiana showing crystal structures. (Note: Digestive zone $($ scale bar $=100 \mu \mathrm{m})(\mathrm{A})$; waxy zone $($ scale bar $=100 \mu \mathrm{m})(\mathrm{B})$; a prism crystal $($ scale bar $=30 \mu \mathrm{m})$ (C); a druse crystal (scale bar $=30 \mu \mathrm{m})(\mathrm{D})$. KR: Crystal)

mal cells [20]. The nectary glands often abundantly occur at peristome, which is a collar-shaped structure surrounding and overhanging at the mouth of the pitchers [20].

The structure of pitcher transverse section is cuticle layer at the inner and outer surface, inner and outer epidermis layer and undifferentiated mesophyll layer (Figure 9 and Figure 10). This mesophyll is lacking of air spaces. The inner surface of the upper half pitcher lined with either secretory or digestive glands (Figure 9). The secretory gland showed at transverse section of upper half pitcher are lunate cells (a stomata-like struc- ture with a single guard cell) (Figure 9). The lunate cells are coated by a thick layer of epicuticular wax forming loose scales [9]. The digestive glands are noticeable as an ovoid-spherical structure of three cell layers protected by hooded ridges. This hooded ridge comprises a modified epidermal cell extending over at least part of the depression [28]. The first layer is called the glandular head, consist of multicellular masses of tissue with the outermost layer of cells are columnar $[14,9]$. The second and the third layers are thinner than the first one and have various shape. The digestive glands that immersed in cavity were distributed on the 
lower half pitcher of all the observes species (Figure 10).

Spiral elements were observed at the transverse section of leaves, pitchers, and pitcher's lids (Figure 7, 8, 9, 10). This structure is common for Nepenthes [14]. It was noticed that the spiral elements were frequently found between digestive glands and seem to connect them.

Prism and druse crystal structures scattered in the hypodermic layer, mesophyll tissue and vascular bundle were found at the pitcher transverse sections of $N$. rafflesiana (Figure 11). Such a crystal structure is absent at the other four Nepenthes species. However, stellate crystals were reported found throughout the pitcher of N. alata [9]. Presumable, the crystal found in Nepenthes is calcium oxalate. The crystals of plants are commonly found in idioblast cells, but can also be stored in the epidermal cell, palisade, and vascular bundle [29]. It was reported that the presence and shape of crystal are determined by genetic factors, this character constant for a species [30] and is a valuable taxonomical character [31]. This character has been reported to be used to distinguish groups of monocots at the family level [32].

\section{The character used in separating the Nepenthes species of Bangka Belitung}

Five species of Nepenthes from Bangka Belitung islands could be identified based on the anatomical characters of leaf epidermal cell, the presence of nectary glands at the abaxial surface of pitcher lid, the presence of crystal at the parenchymal tissue of pitcher transverse section, and the length of lunate cells (compared with the epidermal cells) at the inner surface of the upper half pitchers. These first three anatomical character is a good character since it is fixed and genetically inherited. However, the length of lunate cell is less valuable because it is probably various and affected by environment or growth stages.

The identification key for five species Nepenthes from Bangka Belitung Islands based on anatomical characters:

1. a. Nectar glands are absent in the abaxial of pitcher lid

b. Nectar glands are present in the abaxial of pitcher lid .......................................................... 3

2. a. The anticlinal wall of leaf epidermal cell is sinuous $N$. gracilis b. The anticlinal wall of leaf epidermal cells is straight N. ampullaria

3. a. Prism and druse crystals occur in the cells distribute at parenchyma tissue of pitcher transverse section N. rafflesiana

b. Crystals are not found at the pitcher tran verse section 4

4. a. The lunate cells (observed at paradermal section) are shorter than the epidermal cells N. mirabilis

b. The lunate cells are longer than the epidermal cells N. reinwardtiana

\section{Conclusion}

The anatomical characters of leaf, pitcher, and pitchers' lid could be used for differentiating the five species of Nepenthes from Bangka Belitung Islands. The presence of crystal at the parenchymal tissue of pitcher differentiate the species $N$. rafflesiana from the four others. The absence of nectary gland at the abaxial surface of pitcher lids of the species $N$. gracilis and $N$. ampullaria separate them from the others species. The leaf epidermis of these two species have different cell wall. The length of lunate cells at the inner surface of upper half pitchers are comparable for identifying the pitchers of $N$. mirabilis from those of $N$. reinwardtiana. For the conclusion, in identifying the Nepenthes, the anatomical characters could be used for supporting the morphological character.

\section{Acknowledgment}

This research is funded by Non-Degree Superior Scholarship P3SWOT Batch 12016 DIKTI. The authors are grateful to the Government of Bangka Belitung Islands Province for the approval to conduct the research, and the Forest Service of East Belitung Regency for all the support during the field works in Belitung. The authors would like to thank Prof. Mien A Rifai and Mr. Mansur from LIPI, Cibinong for their support and guidance during the research.

\section{References}

1. Mansur M (2013) Tinjauan tentang Nepenthes (Nepenthaceae) di Indonesia. Berita Biologi 12 (1): 1 - 7.

2. CITES (2017) Convention on international trade in endangered species of wild fauna and flora: Nepenthes. https://www.cites.org/eng/search/site/nepenthes. Accessed date: 1 October 2017. 
3. Hidayat S, Hidayat J, Hamzah et al. (2003) Vegetation analysis of two insectivorous plants in Padang Pinang Anyang, Belitung Island. Biodiversitas 4 (2): 93 - 96. doi: 10.13057/biodiv/d040 205.

4. Latifah S (2003) Kegiatan reklamasi lahan pada lahan bekas tambang. http://library.usu.ac.id/. Accessed date: September 2018.

5. Cheek M, Jebb M (2013) Nepenthes ultra (Nepenthaceae), a new species from Luzon, Phillipines. Blumea 58 (3): 241 - 244 doi: 10.3767/000651913X675124.

6. Gronemeyer T, Coritico F, Wistuba A et al. (2014) Four New Species of Nepenthes L. (Nepenthaceae) from the Central Mountains of Minadano, Phillipines. Plants 3 (2): 284 - 303. doi: 10.3390/plants3020284.

7. Gronemeyer T, Suarez W, Nuytemans H et al. (2016) Two New Nepenthes species from the Philippines and an amended description of Nepenthes ramos. Plants 5 (2): 23 - 37.

8. Gaume L, Gorb S, Rowe N (2002) Function of epidermal surfaces in the trapping efficiency of Nepenthes alata pitchers. The New Phytologist 156 (3): 479 - 489. doi: 10.1046/j.14698137.2002.00530.x

9. Owen PT, Lennon KA (1999) Structure and development of the pitchers from the carnivorous plant Nepenthes alata (Nepenthaceae). American Journal of Botany 86 (10): 1382 - 1390.

10. Arimy NQ, Nisyawati, Metusala D (2017) Comparison of leaf anatomy on some Nepenthes spp. (Nepenthaceae) from highland and lowland habitat in Indonesia. In AIP Conference Proceedings 1862 of International Symposium on Current Progress in Mathematics and Sciences: 1- 2 November 2016; Depok. Edited by: Mart T, Triyono D, Sugeng KA. doi: 10.1063/1.4991215.

11. Gaume L, Di Giusto B (2009) Adaptive significance and ontogenetic variability of the waxy zone in Nepenthes rafflesiana. Annals of Botany 104 (7): 1281 - 1291. doi 10.1093/aob/mcp238.

12. Osunkoya OO, Muntassir NA (2017) Comparative anatomy of the assimilatory organs of Nepenthes species. Australian Journal of Botany 65 (1): 67 - 79. doi: 10.1071/BT16157.

13. Sass JE (1951) Botanical microtechnique $2^{\text {nd }}$ edition. Iowa, Iowa State College Press.

14. Metcalfe CR, Chalk L (1950) Anatomy of Dicotyledons: Leaves, stem, and wood in relation to taxonomy with notes on economic uses (Nepenthaceae) Volume III. London, Oxford at the Clarendon Press.

15. Stone BC (1977) The Morphology and systematics of Pandanus today (Pandanaceae). Gardens Bulletin 29 (4): 137 - 142

16. Nurit-Silva K, Costa-Silva R, Basilio IJL D, de Fatima Agra M (2012) Leaf epidermal characters of Brazilian species of Solanum section Torya as taxonomic evidence. Botany 90 (9): 806 - 814. doi: 10.1139/b2012-046.

17. Damayanti F, Roostika I, Mansur M (2015) Kajian morfologi, sitologi dan struktur anatomi daun Nepenthes spp. asal Kalimantan Barat. Bioedukasi: Jurnal Pendidikan Biologi 8 (2): 5 - 11. doi: 10.20961/bioedukasi-uns.v8i2.3862.

18. Chen CC, Chen YR (2005) Study on laminar hydatodes of Ficus formosana (Moraceae) II. Botanical Bulletin - Academia Sinica Taipei 46: $205-215$

19. Benz MJ, Gorb EV, Gorb SN (2012) Diversity of the slippery zone microstructure in pitchers of nine carnivorous Nepenthes taxa. Arthropod-Plant Interactions 6 (1): 147 - 158. doi: 10.1007/s11829-011-9171-2.

20. Moran JA, Clarke CM (2010) The carnivorous syndrome in Nepenthes pitcher plants: Current state of knowledge and potential future directions. Plant signaling and Behavior 5 (6): 644 - 648. doi: 10.4161/psb.5.6.11238.

21. Sutrian Y (1992) Pengantar anatomi tumbuh-tumbuhan. Jakarta, Rineka Cipta.

22. Moran JA, Clarke CM, Hawkins BJ (2003) From carnivore to detritivore? Isotopic evidence for leaf litter utilization by the tropical pitcher plant Nepenthes ampullaria. International Journal of Plant Science 164 (4): 635 - 639. doi: 10.1086/375422.

23. Adamec L (1997) Mineral nutrition of carnivorous plants: A review. Botanical Review 63 (3): 273 - 299. doi: 10.1007/2FBF02857953.

24. Wang LX, Zhou Q (2011) Friction force of locust Locusta migratoria manilensis (orthoptera, Locustidae) on slippery zones surface of pitchers from four Nepenthes species. Tribology Letters 44: 345 - 353. doi: 10.1007/2Fs11249-011-9858-7.

25. Riedel M, Eichner A, Meimberg H, Jetter R (2007) Chemical composition of epicuticular wax crystals on the slippery zones in pitcher of five Nepenthes and hybrids. Planta 225 (6): 1517 1534. doi: 10.1007/2Fs00425-006-0437-3.

26. Haberlant G (1914) Physiological plant anatomy. Macmillan and Company, London.

27. Fahn A (1979) Secretory tissues in plants. New York, Academic Press.

28. Gorb E, Kastner V, Peressadko A et al. (2004) Structure and properties of the glandular surface in the digestive zone of the pitcher in the carnivorous plant Nepenthes ventrata and its role in insect trapping and retention. The Journal of Experimental Biology 207: 2947 - 2963. doi: 10.1242/jeb.01128.

29. Faheed F, Mazen A, Abd Elmohsen S (2013) Physiological and ultrastructural studies on calcium oxalate crystal formation in some plants. Turkish Journal of Botany 37: 139 - 152. doi: 10.3906/bot-1112-19.

30. Fritsch FE (1903) The use of anatomical characters for systematic purpose. New Phytologist Journal 2 (8): 177 - 184. doi: 10.1111/j.1469-8137.1903.tb04972.x.

31. Prychid CJ, Rudall PJ (1999) Calcium oxalate crystals in Monocotyledons: A review of their structure and systematics. Annuals of Botany 84 (6): 725 - 739. doi: 10.1006/anbo.1999.0975.

32. Wang L, Zhou Q (2014) Nepenthes pitchers: surface structure, 
physical property, anti-attachment function and potential application in mechanical controlling plaque locust. Chinese Science
Bulletin 59 (21): 2513 - 2523. doi: 10.1007/2Fs11434-0140383-6. 